Journal of Humanities and Social Sciences Studies (JHSSS)

ISSN: 2663-7197

DOI: 10.32996/jhsss

Journal homepage: https://al-kindipublisher.com/index.php/jhsss

\title{
Religious Consciousness in Joseph Conrad's Heart of Darkness and James Joyce's A Portrait of the Artist as a Young Man
}

Amungwa Veronica Nganshi ${ }^{1 *}$, and John Nkemngong Nkengasong ${ }^{2}$

${ }^{1}$ PhD, Adjunct lecturer, English Department, University of Buea, Cameroon

${ }^{2}$ Professor of English Literature and Dean of Faculty of ArtsUniversity of Buea, Cameroon

Corresponding Author: Amungwa Veronica Nganshi, E-mail: nganshi39@gmail.com

\section{ARTICLE INFORMATION}

Received: October 17, 2020

Accepted: November 18, 2020

Volume: 2

Issue: 6

DOI: 10.32996/jhsss.2020.2.6.17

\section{KEYWORDS}

Religious consciousness, modernist novel, Catholic faith, autobiographical element, nihilism, Conrad, Joyce

\section{ABSTRACT}

The paper examines religious consciousness in the modernist novels of Joseph Conrad's 1902 Heart of Darkness and James Joyce's 1916 A Portrait of the Artist as a Young Man with the objective of illustrating that though these writers apparently rejected the Catholic faith, they were still spiritually conscious and were thus able to detect and question religious values that were repressive. This consciousness is enriched by autobiographical elements prompted by the nihilism of the early twentieth century. Although Heart of Darkness is a colonial novel and A Portrait of the Artist as a Young Man traces the development of a potential artist, both converge on the critique of religious hypocrisy and injustice. Using the concepts of psychobiography, the conscious and unconscious of the Psychoanalytic theory as well as the concept of nihilism of the Modernist theory, the paper demonstrates that both Conrad and Joyce effectively make a critique of religion by the inclusion of various aspects of their real life experiences in their novels. They do this not to reject religion per se but for its reformation. In other words, the religious views of the protagonists in both works reflect those of their authors. Both authors portray not what is dominantly fictional but what they were a part of. This paper's significance is its projection of the notion that it is the exploration of religious consciousness from an autobiographical perspective that gives the British modernist novel its strength and major difference. Conrad and Joyce demonstrate that without sincerity, justice, restraint, controlled freedom and mutual respect, the individual and society degenerate. Literature serves as a fabric of culture with the writer as the voice of conscience.

\section{Introduction}

The modernist novel is one written between 1890 and 1945 with characteristics that are different from the traditional or Victorian novel. Modernism is defined in A Glossary of Literary Terms as a term "widely used to identify new and distinctive features in the subjects, forms, concepts, and styles of literature and the other arts in the early decades of the twentieth century, but especially after World War 1" (Abrams, p. 175). Many critics agree that modernism involves a deliberate and radical break with some of the traditional bases not only of Western art, but of Western culture in general. The development of modern industrial societies with sophisticated weapons subjected humanity to the horrors of the First World War with its alarming death toll and the economic depression which left people wondering about the possibility of attaining their ideal vision. Modernist writers, therefore, were forced to reconsider the validity and value of any civilisation Europe could claim. Writers, like Virginia Woolf, E.M. Forster, D.H. Lawrence, Ford Madox Ford, William Faulkner, Marcel Proust, Joseph Conrad and James Joyce saw traditional forms and social arrangements as hindering progress and therefore the artist was recast as a revolutionary, overthrowing rather than enlightening. The view that mankind was making slow and steady moral progress seemed ridiculous in the face of the senseless slaughter of the Great War. As avant-garde artists, they created new forms 
and style and introduced hitherto neglected and forbidden subject matter. For instance, Conrad and Joyce glaringly criticize colonialism and the values and teachings of Catholic Church.

Some philosophies and ideologies came up to challenge these values of Western civilisation. Charles Darwin's theory of evolution by natural selection was for instance nihilistic as it undermined religious certainty of the general public. The notion that human beings were driven by the same impulses as lower animals proved to be difficult to reconcile with the idea of an ennobling spirituality. Stevenson (1998) posits that Darwin demonstrated that species evolved through natural selection, rather than divine ordering and control (p.72). The effect of his theory was to offer scientific support for racism, eugenics and the undermining of the Judeo-Christian natural law (De Marco \& Wiker, p. 9). Karl Marx stipulated that problems with the economic order were not transient, the result of specific wrong doers or temporary conditions, but were fundamentally contradictions within the capitalist system. Marx thus filled the consciousness of people with revolutionary doctrines that not only revealed how much the lower class has been exploited over the ages but also provided structures for them to rebel against the status quo. Marx offers a surrogate religion. Love is missing from his promise of justice, redemption, joy, equality, community and even a utopian paradise. The absence of love renders it empty and useless (De Marco \& Wiker, p. 12). Love is the badge of the spiritual life of a Christian as echoed by Pope Francis (2020) in his recent encyclical letter on solidarity and friendship when he states that:

The spiritual stature of a person's life is measured by love, which in the end remains the criterion for the definitive decision about a human life's worth or lack thereof. Yet some believers think that it consists in the imposition of their own ideologies upon everyone else, or in a violent defence of the truth, or in impressive demonstrations of strength. All of us, as believers, need to recognize that love takes first place: love must never be put at risk, and the greatest danger lies in failing to love (No 92, p. 24).

Similarly, Sigmund Freud's psychoanalysis influenced modernist consciousness as he understood the human being as irrational and driven by unconscious forces, suppressed dreams and sexual desires. Interest in the mysterious and unconscious self, led modernist writers to emphasise areas of experience previously of much more limited concern to the novel. Modernist writers therefore embarked on psychological realism. Freud's rejection of religion, distrust of fatherhood, suspicion of morality, and reduction of love to sex has unleashed a plague of problems that has produced widespread and adverse effects. Another doctrine that professed nihilism was Jean Paul Sartre's Existentialism. Though Joseph Conrad and James Joyce rejected the Catholic faith, they were still spiritually conscious and were thus able to detect and question norms that were repressive. Both were born in deeply Catholic countries; Poland and Ireland. Consequently, they were deeply entrenched in Catholic values which could not be shaken off completely.

In Conrad's work, religion is implicit while it is explicit in Joyce's work. The experiences of Conrad and Joyce as echoed by their protagonists are traceable to early childhood. The analysis will focus on the Catholic upbringing of Conrad and Joyce and how it influences their spiritual consciousness and vision as explorer and artist respectively.

\section{Literature Review}

Conrad and Joyce, as highly acclaimed writers, have received a lot of criticism in their works but very little in a comparative analysis in general and with focus on religion in particular. Comparatively, Gallacher (2017) discusses the centrality of place (setting) in modernist prose texts with focus on Conrad's Heart of Darkness and James Joyce's A Portrait of the Artist as a Young Man (p.59). Szczeszak-Brewer (2010) demonstrates the ways in which these authors grapple with the issues of the grand narrative, paralysis, hegemonic practices, the individual's pilgrimage toward self-definition- within the rigid bounds of imperial ideologies and myths. Neary (1999) focuses on religious consciousness. In a comparative method in Like and Unlike God: Religous Imaginings, Neary argues that Conrad's religious imagining calls attention to the gaping tension between traditional human virtues and radically relativised forms while Joyce's tend to create bridges and linkages to heal this tension. Lewis (2000) in Modernism, Nationalism and The Novel, rereads four major subjectivist novels-James Joyce's A Portrait of the Artist as a Young Man, Joseph Conrad's Heart of Darkness, Marcel Proust's A La Recherche du temps perdu, and Gabriele d'Annunzio's Nocturne-in a context of the period's political discourse of liberal nationalism, providing a timely and historicist reassessment of modernist politics and the modern novel. Lewis demonstrates that these novelists used their subjectivist experiments with narrative and point of view (impressionism and stream of consciousness) to focus "attention on the shaping of the individual by the nation and on the potential for the individual in turn to redeem the nation in time of war or crisis" (p.11). Ford (1985) declares that Conrad and Joyce shared forty- two years of common life span, twenty- two years of simultaneous creative output and a number of mutual friends and contacts in the literary world (p.59) and that: "Both artists were voracious readers who wrote their own letters in three languages, and their common literary heritage, grounded on the bible and classical mythology, is sufficiently we known..." (59). 


\section{Methodology}

This paper uses the psychoanalytic and modernist perspectives because the experiences of Conrad and Joyce as echoed by their protagonists are traceable to early childhood while the questioning of religion reflects the modernist experience. Therefore, the Freudian psychoanalytic concepts of psychobiography, the conscious and unconscious are useful while nihilism is the key concept in the modernist theory. Psychoanalytic criticism originated in the work of Austrian psychoanalyst Sigmund Freud. Freud had developed the dynamic form of psychology that he called "psychoanalysis" as a procedure for the analysis and therapy of neuroses, but soon expanded it to account for many developments and practices in the history of civilization, including warfare, mythology, and religion as well as literature and the other art forms. Freud also concentrated on dreams and neurotic symptoms which consist of the imagined or fantasized fulfillment of wishes that are either denied by reality or prohibited by the social standards of morality and propriety. Psychological criticism examines the behaviour of characters within the text in order to unearth its deeper meaning.

Psychoanalysis is geared towards understanding individuals by uncovering desires hidden deep within the mind and revealing their connections with the unconscious surface. In literature, however, psychoanalytic critics believe that the unconscious mind of the author is revealed in his works. Thus, the psychoanalytic critic may begin with a study of the elements in a writer's biography that shape his imagination and then apply this to the work. He may also use the work as the equivalent of a confession and then go on to draw conclusion about the writer from this. Psychoanalytic criticism believes that literature provides a fruitful and complex source for the analysis of the human mind. It helps to reveal to us things about the relation between the conscious and the unconscious mind, language and reality. A psychoanalytical interpretation of a work can help to solve the mysteries involved in complex and symbolic themes.

Embracing change, modernism encompasses the works of thinkers who rebelled against nineteenth century academic traditions, believing the traditional forms of art, architecture, literature, religious faith, social organisation and daily life were becoming outdated. A growing distrust in rationality partly stemmed from the misuse of technology for massive killing of people during World War I and partly from the philosophic ideas of Frederich Nietszche and the psychology of Sigmund Freud who expressed a skeptical view on man during the period of growing industrialisation, commercialism and consumerism. Sigmund Freud's psychoanalysis influenced modernism as he understood the human being as irrational and driven by unconscious forces, suppressed dreams and sexual desires.

\section{Results and Discussion The Catholic Upbringing of Conrad and Joyce}

Consciousness in the twentieth century, be it individual, socio-political, moral, artistic or spiritual was conditioned by a number of factors deriving from the nineteenth century; namely the industrial revolution, Marxism, Freudianism, Colonialism, Darwinism, Existentialism among others which all tended towards nihilism. Conrad and Joyce thus represent consciousness impacted by the nihilism of the era and craft characters based on personal experiences in the novels. Both writers were brought up as Roman Catholics, both rejected Catholicism at a later stage, both went into self-exile but their novels are entrenched with religious values.

Conrad was born in the Ukraine in 1857 as Jozef Teodor Konrad Nalc;cz Korzeniowski, the son of a father who was deeply imbued with the Messianic visions of Poland's romantic poets. Significantly, Conrad's first sense of identity was that of 'Pole, Catholic, nobleman', expressed by him at the age of five in a letter to his grandmother. Earlier, his baptism had been greeted by Apollo Korzeniowski with verses that exemplify the father's nationalistic beliefs as reported by Lester (1987): "My child, my son, if the enemy calls you a nobleman and a Christian - tell yourself that you are a pagan and that your nobility is rot. . . My child, my son - tell yourself that you are without land, without love, without Fatherland, without humanity - as long as Poland, our mother, is enslaved" (p.7). This intense patriotic passion prompted a move to Warsaw where Apollo's fiery political activities led to his arrest in October 1861 and subsequent exile to Northern Russia with his family during the following May. Both Conrad and his mother, Evalina, suffered from severe illness during the journey and for a while the boy was near to death. When death did come, however, it claimed his mother in 1865 and his father four years later. In a sense, then, Conrad's childhood epitomises the fate of Poland during these years. Inspired by a deep religious nationalism, evoked by the great romantic poets, Apollo, unwittingly, led his family to disaster. As a very young child Conrad seems to have held a simple belief, asking the poor at the church 'to pray for the return of his father from Warsaw' (Leste, p. 7).

Ellmann (1983) writes that James Augustine Aloysius Joyce was born on 2 February 1882 to John Stanislaus Joyce and Mary Jane Murray in the Dublin suburb of Rathgar. He was the eldest in a family of four boys and six girls. Joseph Conrad on the other hand was an only child. Joyce's father, John Joyce had inherited property in his home town, Cork and was Collector of 
Rates for Dublin at the time of James's birth. It was an undemanding, well-paid post, but John Joyce was a reckless spender and a heavy drinker, and he had begun to mortgage his Cork properties as early as 1881 . As his family grew in number, so did the mortgages (eleven altogether). In 1892, his post was abolished and he was pensioned off at the age of forty-two. Thereafter, a rapid decline in the family fortunes set in. James had been sent to Clongowes Wood College, a highly thought of Jesuit school in county Kildare, but was withdrawn in 1891 after three years there. He spent some time at a Christian Brother's School until Father Conmee, former rector of Clongowes who knew him as a very promising pupil, kindly arranged for him to have a free place at Belvedere College, the Jesuit School in Dublin:

Just now John Joyce, walking in Mountjoy Square one day, had a fortunate encounter with Father John Conmee, who had left the position of rector of Clongowes to become prefect of studies at Belvedere College. Conmee kindly offered to arrange for James, and his brothers too, to attend the fine Jesuit day-school, Belvedere College, without fees (p.35).

Joyce will echo this life experience in A Portrait of the Artist as a Young Man by narrating how Stephen's father (Simon Dedalus) arranges with Father Conmee for his admision into Belvedere College (pp.65- 66). Joyce uses the real name of the priest and school in his novel to show how his consciousness was impinged by this kind gesture. At first Joyce worked well at Belvedere: he won exhibitions in annual examinations and was noted for his piety, becoming head of the Sodality of the Blessed Virgin Mary in 1869. However, it appears that in that same year, at the age of fourteen, he met a prostitute one night and had his first sexual experience. Not long afterwards, in a school retreat conducted by Father James A. Cullen at the end of November and at the beginning of December 1896, Joyce was deeply stirred by guilt feelings, went to confession, and for some months tried seriously to live a life of piety (Ellmann, pp. 48-49). But his faith then began to disintegrate. He rejected the suggestion to become a priest and became more careless in his studies.

Concerning the influence of religion on Conrad's upbringing, Lester states that Conrad's earliest religious background was that of Polish Catholicism. Under the oppressive yoke of the occupying powers, particularly Russia, Polish religion became intensely nationalistic and its principal features frequently appear as elements of his fiction (1). Conrad's dislike for Christianity began two years after the death of his father (Lester 77). The tragic death of his parents made him see religion and Christian virtues as hypocritical. He even considers the practice of virtue as criminal as he declares: "abnegation carried to an extreme becomes not a fault but a crime". To him, not to pay evil with evil "develops that latent tendency towards hypocrisy" (p.8). He would project this tendency to hypocrisy in Heart of Darkness where the Europeans exploit, oppress and suppress the Africans under the guise of civilization and evangelisation. On the other hand, though Conrad became lukewarm to his faith, there were moments he identified himself as a Catholic, as Jessie reveals when describing how J.B. Pinker, aided by Protestant Swiss waiters, parodied a Catholic procession; the fun coming to an abrupt end at the Conrad's sitting-room door when Conrad "flung it open and said icily: "Yes, and I'm a catholic, aren't I?'" Jessie continues, "I heard the singer's voice murmuring insinuatingly. I could not catch what was said, but the effect was a peal of amused laughter from the 'Catholic' and I knew the storm was over" (Lester, p. 94). In another instance Conrad's attitude is shown by citing a letter from him in which he refuses to join a London club:

I was born a R.C. and though dogma sits lightly on me I have never renounced that form of Christian religion... I do not think it would be correct for me to ask you to put my name down, and indeed I do not think it could be done since one of the conditions of membership is to be a Protestant (p.94).

Whilst Conrad was not a practising catholic, he never revoked his faith, and he did, indeed, receive a Catholic burial on his death. It is also clear that he was not willing to allow his erstwhile faith to be attacked in his hearing or to join any organisation which would effectively force him to disavow it.

Focusing on Joyce's influence with religion, Segall (1993) reports that Joyce, later in life, reconciled with the faith he rejected earlier in life and that his parting with the faith was succeeded by a not so obvious reunion, and that Ulysses and Finnegans Wake are essentially Catholic expressions (p.120). Likewise, Hugh Kenner and T.S. Eliot saw between the lines of Joyce's work the outlook of a serious Christian and that beneath the veneer of the work lies a remnant of Catholic belief and attitude (qtd Segall, p.142). Somewhat cryptically, in an interview after completing Ulysses, in response to the question "When did you leave the Catholic Church", Joyce answered, "That's for the Church to say." There are different first- hand testimonies coming from Joyce, his brother Stanislaus Joyce and his wife about his attitude toward religion:

Six years ago I left the Catholic Church, hating it most fervently. I found it impossible for me to remain in it on account of the impulses of my nature. I made secret war upon it when I was a student and declined to accept the positions it offered me. By doing this I made myself a beggar but I retained my pride. Now I make open war upon it by what I write and say and do (Ellmann, Selected Letters, pp.25-26). 
Joyce reflects his hostility to religion in his novel when Stephen replies to Cranly's question if he intended to become Prostestant by saying: "I said that I had lost the faith, Stephen said, but not that I had lost self- respect" (p.220). Stanislaus Joyce's (1958) own testimony about Joyce's attitude towards religion is that:

My brother's breakaway from Catholicism was due to other motives. He felt it was imperative that he should save his real spiritual life from being overlaid and crushed by a false one that he had outgrown. He believed that poets in the measure of their gifts and personality were the repositories of the genuine spiritual life of their race and the priests were usurpers. He detested falsity and believed in individual freedom more thoroughly than any man I have ever known (p. 120).

From this view it is clear that Joyce was a man of conviction who hated hypocrisy and "believed in individual freedom". However, individual freedom does not mean indulging in one's whims and caprices. This is why Burke (2007) explains that the presence and operation of human freedom means that there is no such thing as automatic fulfillment for anyone. Man is free but not autonomous. He is free but not independent. His own capacities limit him physically and psychically (pp.18-19). Joyce echoes his conviction in A Portrait of the Artist as a Young Man with his non serviam statement: "I will no longer serve that in which I no longer believe whether it call itself my home, my fatherland or my church" (p.222). He goes on to declare that "I am not afraid to make a mistake, even a great mistake, a lifelong mistake" (p.223). He is therefore determined to bear the consequences of rejecting his religion, family and country because he is convinced he is doing so for a good cause. Bulson, states that when asked by a catholic priest if she wanted a religious service for Joyce's funeral, Nora refused; "I couldn't do that to him."

\section{Spiritual Consciousness of the Explorer and the Artist}

Although the modernist period was pervaded by the loss of faith and certainty and a sense of fragmentation and alienation in an atmosphere of disillusionment, Conrad and Joyce were still spiritually conscious. Lewis (2006) commenting about the modernist writer's attitude toward religion comments that:

Accounts of the period often emphasize the influence of the secularization and the diminished significance of organized religion for many modern writers. It is equally important, however, to recognize the modernists' continued search for answers to traditional religious questions about the human condition, the nature of historical experience, sexuality, death, and ultimate realities. The search for "substitute[s) for religion" played a crucial role in the development of literary modernism because the most important substitute for religion that the modernists found was literature itself (pp.19-20).

Nevertheless, experience proved that religion could not be entirely discarded as Pericles comments:

The interest in representing religious experience is shared by modernists with widely differing religious affiliations. Eliot converted to Anglo-Catholicism. Auden, after losing his faith and discovering his vocation as a poet at age 15, returned to the Anglican Church in his early thirties. Joyce was a lapsed Catholic. In the late 1920s and early 1930s, a period of Catholic renewal, a number of artists and intellectuals converted to Roman Catholicism, notably two young novelists influenced by modernism, Evelyn Waugh and Graham Greene (p.24).

Conrad and Joyce rejected formal religion and yet remained preoccupied with it as evidenced in their novels. Having grown up in deeply Catholic countries, religious values were deeply ingrained in these two writers and they were able to identify and glaringly criticise the nihilistic practices in their societies. Lester comments about Conrad's attitude towards religion by writing that:

whilst Conrad was not a practising catholic, he never revoked his faith, and he did, indeed, receive a Catholic burial on his death, attended by "the blessed mutter of the mass," as Cunninghame Graham put it, quoting (with unintentional irony) the words of a Protestant. It is also clear that he was not willing to allow his erstwhile faith to be attacked in his hearing or to join any organisation which would effectively force him to disavow it, though both these factors could be explained as simple defence of heritage (pp.94-95).

In Heart of Darkness Conrad condemns the materialism set up by modern man to replace God. Commenting about the replacement of God by materialism, Father Barron (2015) writes that:

We are built for worship, and therefore in the absence of God, we will make some other value our ultimate concern. Wealth, power, pleasure, and honour have all played the role of false gods over the course of the human drama, but today especially, freedom itself has emerged as the ultimate good, as the object of worship (www.zenith.org). 
Uncontrolled freedom in the modernist era led to idolatory which replaced spiritual values. In Heart of Darkness there is the idolatory or religion of ivory to which the Europeans pray. Raskin (1967) posits that although Conrad believed there is no real religion without a little fetishism, he believed that Christianity was dying and that new secular religions were taking its place. As the old gods died man made new ones and this process was common to primitive and civilized men (p.126). The deification of wealth, political power, and secular values were indications that man's creations assumed power over him, that man was estranged from the world around him. In Heart of Darkness there is the religion of ivory as well, the ivory to which the white traders pray: "The word 'ivory' rang in the air, was whispered, was sighed. You would think they were praying to it" (p.1775). Kurtz stands at the 'heart of darkness' for he has become a god worshipped by the Africans and thus totally dehumanized. This is a direct comment on the colonialist world, for many had written, as Kurtz did, that whites must appear 'in the nature of supernatural beings ... with the might as of a deity', to 'exert a power for good' (1772). In presenting Kurtz as such, Conrad critiques those Europeans who reject their Christian values in favour of materialism and idolatory.

Conrad in his works makes frequent references to the Scriptures. In Heart of Darkness, he subtly makes jest of the colonialists' misuse of religion by using Marlow to compare imperialistic occupation in Africa to that of the Roman occupation of Britain in the 5th century. In the same way as the Roman conquerors once spread "civilization" to England, Marlow states, the Thames, representing the heart of Empire, has continued to send out her missionaries and explorers to bring light into darkness. Here Conrad's irony is built on the contrasts between light and darkness, between white and black, between socalled civilization and so-called barbarism. Torches, fires and sunlight are contrasted to shadows, haze and darkness. All builders of empire: missionaries, explorers, traders, soldiers and conquerors, regardless of where they came from, become the targets of Conrad's irony. By claiming to preach the gospel to the colonised, they sought to keep them in a state of inertia. It is for this reason that Nietzsche described religion as the morality of the weak or slave morality while Karl Marx described it as the opium of the people because most of the time it is the misuse of religion that makes the exploited masses accept their fate. The European nations first entered the native countries to preach love and hope through Christianity, and later the Christian missionaries became one of the ways to rule the natives. Because of the faith in Christianity, the workers accept not only their fate but also the hypocrisy of their religious leaders. It is utter hypocrisy for the whites to preach equality but treat the blacks with disdain. Even the Bible is not in support of slavery and oppression as perpetuated by the whites. Thus Conrad condemns the misuse of religion for ulterior motives and not religion per se.

After Marlow's journey into the Congo, he gained experience and knowledge just like Conrad about the malignant, evil and nihilistic heart of man. From this backdrop, Conrad sees religion being used as a camouflage. The comparison of the Congo River to a snake evokes Paradise and the Fall and contributes to the idea that Africa attracts the quester, seduces and gives him knowledge that will be very hard to live with. Throughout the book, and especially in the early sections, Marlow repeatedly refers to the Congo River as a snake. He tells of his childhood fascination with maps and how the river resembled "an immense snake uncoiled" (1763). Like Eve, Marlow is tempted and overcome by the river Congo which is referred to as a snake. Marlow declares: "The snake had charmed me" (1764).

Marlow is able to overcome the temptation of the snake while Kurtz and the other Europeans fall into the evil of greed, hypocrisy and cruelty. The ironic appellation of 'pilgrims' emphasises that nobody in the novel is faithful to any redeeming idea, arguably not even Marlow whose only idea in a senseless confusing world is to do his captain's work. Some religious references expose the questionable value system of society such as the reference of Belgium to a "whited sepulcher" (p.1765) from Matthew 23: 27 which Jesus used to condemn the hypocrisy of the Pharisees. The labourer "worthy of his hire," (p.1767) which Marlow's aunt cites to justify Marlow's hint that the Company was run for profit, is an ironic allusion to the religious rationale that is linked with other motives for imperialism. Some allusions evoke disillusionment such as the ironic echo of Bunyan's The Pilgrim's Progress in the word 'pilgrims': “...they were all waiting- all the sixteen or twenty pilgrims of them- for something... They beguiled the time by backbiting and intriguing against each other in a foolish kind of way...They intrigued and slandered and hated each other..." on account of ivory (1766). This backbiting is a factual reference of which Conrad wrote in his Congo diary that the prominent characteristic of the social life in the Congo is people speaking ill of each other (qtd in Raskin, p. 117).

Conrad scholars have also found parallels with the Faustus legend, suggesting that Christopher Marlowe inspired not just the name of Conrad's narrator but also an intertextual relationship. Both stories deal with characters that challenge the powers of the unknown for filthy lucre, who bring disaster to themselves and others and who make a pact with the devil. Marlow finds that Kurtz "had taken a high seat among the devils of the land," and argues that "no fool ever made a bargain for his soul with the devil" (p.1795). Kurtz crosses the borderline of the forbidden and turns into a devil. It is also worth noting that Marlow comes across a Mephistopheles of papiermaché and that the name of Lucifer carries the double connotations of devil and light-bringer. By establishing an analogy between the modern colonists and the Middle Ages pilgrims, Conrad challenges the readers' knowledge of the benefits of colonization. 
Although the modern colonists look very much like the pilgrims in the Middle Ages, with the staves in their hands reminding of the old palm leaves, Conrad repeatedly and ironically points to the fact that the pilgrims were armed to the teeth. Thus all the essential humanistic values lying at the core of the pilgrimage in Christian terms are questioned and invalidated by the greed, rapacity and violence that characterize the group of people in search for ivory. Wealth, symbolically present under the form of ivory, is the only faith that the white people have. The report that he wrote for the International Society for the Suppression of Savage Customs concluded by "Exterminate all the brutes!" gives the whole dimension of Kurtz's, and implicitly Europe's, colonizing potential.

The ambiguity that Kurtz's last words create, as Conrad chooses to give no clear indication regarding the referent of Kurtz's vision, encourages the interpretation of the novel in terms of various realities, other than the palpable one. In confrontation with the other, the individual manages to discover his hidden, darker self. Marlow is exposed to the evil existing latently in the human heart, and it is only through the bitter experience of evil that he can reach the truth and purify himself to be able to understand the essence of the good. Moreover, Marlow is individually engaged in a process of initiation, which grants him ascendancy on his fellow sailors. He reiterates often enough that he is recounting a spiritual voyage of self-discovery. He remarks casually but crucially that he did not know himself before setting out. Kurtz is willing to sacrifice his life for the sake of honour and wealth. In reality, he ends up losing his soul to the darkness:

He [Kurtz] had taken up a high seat amongst the devils of the land - I mean literally. You can't understand. How could you?... [H]ow can you imagine what particular region of the first ages a man's untrammelled feet may take him into by the way of solitude... by the way of silence - utter silence, where no warning voice of a kind neighbour can be heard whispering of public opinion? (p.1795).

Although Marlow only meets this man very briefly towards the end of his journey, Kurtz makes a strong impression on him from the first time he hears of him. Naturally, Marlow is not the only one who is devoted to Kurtz. A Russian whom Marlow meets at Kurtz's station in the jungle warns him that the savages are unwilling to let him leave. The reason for this, he answers when Marlow asks, is that Kurtz has expanded his mind and that of many others. Marlow notes that this man seems both eager and reluctant to speak of Kurtz, whom he considers to be a sort of god. Again, biblical parallels suggest whether or not God's name is to be taken 'in vain' according to the second commandment. Marlow tells his audience that the Russian was engrossed with Kurtz, and that he constantly thought and talked about him. It seems as if Marlow, too, to some extent begins to understand and admire the evil soul he has come to save: "He won't be forgotten. Whatever he was, he was not common. He had the power to charm or frighten rudimentary souls into an aggravated witch-dance in his honour; he could also fill the small souls of the pilgrims with bitter misgivings..." (p.1801). Looking at Kurtz, one cannot help but think of 'great,' often dictatorial, leaders of the real world, such as Hitler, Mussolini, Stalin, Idi Amin, Bokassa or Mobutu. By inventing someone like Kurtz, it seems as if Conrad anticipated the arrival of these men.

Joyce in his autobiographical novel projects his personal feelings and impression on religious values and their abuse. The Roman Catholic Church was a potent force in Joyce's native Ireland throughout and beyond the nineteenth century, not only in terms of the doctrinal and spiritual guidance it provided but also because of the influence it exerted upon the cultural and political life of the country. Despite Joyce's rejection of the Church's practices in Ireland, Catholicism exerts an immense influence on his artistic life. It is not surprising though, because he received a pure Catholic upbringing since his childhood years. Joyce remained with the Jesuits for about fifteen years. He entered the Jesuit institution at the age of six and a half and left the latter in 1898 at the age of sixteen. He was first educated at the Jesuit College Clongowes Wood, a prestigious Jesuit school in County Kildare. After only two years because of financial constraints he and his brother were enrolled briefly at the Christian Brothers and then as day students at the Jesuit school, Belvedere College. Joyce culminated his studies at the Catholic University of Dublin (Fargnoli, p. 2).

The positive impact of religion on Joyce's upbringing is echoed in the third chapter of $A$ Portrait of the Artist as a Young Man where Stephen does not express disbelief or lack of faith in God. On the contrary he is familiar with the deep tenets of Catholicism. During his schooling at Belvedere, Stephen is known for his piety and is chosen by his peers to be the prefect of the sodality of the Blessed Virgin Mary. Consequently, Stephen draws the attention of the director, who suggests that he consider a vocation to the priesthood. In real life James Joyce had a parallel experience as reported by Ellmann in his biography: "The last appealing voice was that of the director of studies who suggested to Joyce, in a solemn interview when, according to Stanislaus Joyce, the boy was sixteen, that he consider becoming a priest" ( $p .55)$. In the last chapter, Cranly, after a long discussion, concludes that Stephen's mind is supersaturated by the religion he is claiming to reject. Cranly asked Stephen if he believed in the Eucharist to which he answered he "neither believe nor disbelieve". Through his discussion with Stephen, it becomes clear to Cranly that Stephen's mind is supersaturated with the tenets of Catholicism. 
Joyce's conception of himself and his mission as an artist uses the language of priesthood. The novel is full of language strongly linked to religious doctrines and beliefs such as priest, soul, body and sin. Mostly crucial to Joyce's studies when it comes to religion is the influence Saint Thomas Aquinas had on him. Joyce left Ireland loaded with the knowledge he had acquired from the Jesuits. Thus when he said "This race and this country and this life produced me... I shall express myself as I $\mathrm{am}^{\prime \prime}$ (p.202), Joyce is in fact acknowledging his indebtedness to Irish culture and religion in particular which had shaped his mind. Roman Catholicism had long been a focus of nationalist resistance against English colonialism such that "Irishness" had come to be seen by many as synonymous with Catholicism. Richard Ellmann reports in Joyce's biography how the Catholic Church joined forces with others to overthrow Parnell who though he fought for Irish independence was guilty of the sin of the flesh:

When James came home during these Clongowes years, from 1888 to 1891, his father and John Kelly had no subject for talk but Parnell. These were the years during which this unyielding man filled Ireland with his image;... Most young men fancy themselves as Hamlets; Joyce, as later hints make clear, fancied himself as a Parnell. Ireland's 'uncrowned king' was now on his way to becoming her tragic hero... the day before Christmas of that year, 1889, Captain William Henry O'Shea filed a petition for divorce from his wife Kitty on the ground of her adultery with Parnell... and within a year Parnell was dead... and the word betrayal became a central one in Joyce's view of his countrymen (p. 32).

Although Joyce and Parnell's adherents consider his defeat as an act of betrayal, it was strictly not so because his sinful relationship was not an exemplary act of a future leader. The church's role is to uphold upright moral conduct. Though Joyce renounced Catholicism because of the interference of the Church in Irish politics and its attitude to sexual morality, he could not completely detach himself from it. Ellmann in Light Rays: James Joyce and Modernism cites Joyce as saying: "I left the Catholic Church, hating it most fervently. I found it impossible for me to remain in it on account of the impulses of my nature" (p.1). Consequently, it is because of Joyce's refusal to self-mastery that he renounced the faith. His attitude towards religion was ambivalent. In this light therefore, Lewis Pericles in "Modernism and Religion", comments about the modernist's ambivalent attitude towards religion by writing that:

The modernists were not the devout secularists that many critics portray; instead, they were seeking through their formal experiments to offer new accounts of the sacred for an age of continued religious crisis. Joyce's Stephen Dedalus may shun the Catholic Church and Woolf's Mrs. Ramsay chastise herself for thinking, in an unguarded moment, "we are in the hands of the Lord" (To the Lighthouse 101). Yet, their creators continued to search for an adequate account of religious experience, a kind of essence of religion without God or Church, and this search contributed to the development of literary modernism (p.4).

Man is a religious being and can never totally repudiate religion and God because it is deeply ingrained in the conscience. On the other hand, Thomas G. Casey in "The Daedalus Dream" comments that in certain ways, Stephen's beliefs are more rigid than the tradition he rejects. He will not budge in his convictions, irrespective of the suffering he imposes on others (78). Joyce believes that the individuality of the Irish people has been subsumed in a religion whose moral, political and cultural influence denied them any opportunity to make choices for themselves. He feels that the attitude of the mass of Irishmen towards their religion was in the words of Stephen Dedalus, that of "a dull- witted loyal serf" (A Portait 139). Consequently, he isolated himself from the others. Ellmann in James Joyce refers to Joyce's isolation by stating that:

He became more actively different from his parents and teachers... at the end of his schooldays he read Ibsen's sardonic plays. As he said in A Portrait, his soul threw off the cerements that covered it and spurned the grave of boyhood. His sins became serious, and his sense of sin, 'that sense of separation and loss, brought him to consciousness, from which vantage point he sloughed off all but the vestiges of Christian guilt (p.42).

As a potential artist, Joyce was different from his parents and teachers in his outlook. He read lbsen's works and got ideas about exile and the role of the artist in society. These were to influence his opting for a career as an artist rather than a vocation to the priesthood. He realized he could be independent as an artist and thus express his views about his society freely without any constraint. He went through a series of violent changes and emerged from them somber and aloof, except with the few friends to whom he exhibited his joy, his candor, his bursting youth; even with these he was a little strange, "never wholly companionable because each time he laid bare his soul he importuned greater loyalty, until friendship became for them almost an impossible burden of submission" (Fargnoli \& Gillespie, p. 5).

As a result of his Catholic upbringing, Joyce explores the belief in the sacrament of Holy Communion in the incident in which the five boys in Stephen's school steal altar wine from the sacristy. The sacristy is a holy place. The students' theft is not only a crime but is a sin of sacrilege as well. In Catholic doctrine consecrated bread and wine by the priest become the real body 
and blood of Jesus Christ and is reverently adored (Trese, pp. 297-8). As such the bread and wine kept for consecration should be guarded with respect. Only with the eyes of faith can one believe in this sacrament. Freud, who dismisses religion because it cannot be assessed materially, would think otherwise. This is why De Marco \& Wiker (2004) assert that Freud's method of dealing with anything spiritual is reductive (p.18). Freud states that Holy Communion is not what it is believed to be on a spiritual level, but strictly derived from the primitive state of mankind, when cannibalistic ceremonies were practised. Receiving the sacrament of Holy Communion, therefore, is merely what he terms "oral introjections" (p.18). This is a sacrilegious assertion. A materialistic premise can yield only a materialistic conclusion.

Nationality, language, religion, the nets which enclose Stephen as a child and adolescent, are in fact inextricably intertwined, with religion as the central strand. Religion permeates his home life, his induction into the adult world of Irish politics, his school life, his expectations for the future, much of the literature he reads, and even the language with which he expresses himself. An understanding of the interrelationships between Catholicism, family life, guilt, fear and punishment is indoctrinated into Stephen from an early age. As an infant, he says that he will marry Eileen, a protestant. The reaction is unfavourable. He is rebuked by his mother and Dante joins in the reprimand because Catholics and Protestant disagree. Joyce in real life went through this same prohibition from associating with Protestants:

Along the street, at 4 Martello Terrace lived a chemist named James Vance with his family, and although the Vances were Protestant, the families were quickly drawn together. Vance's bass voice boomed against John Joyce's light tenor in 'Come-all-ye's.' The Vances' eldest child, four months younger than James, was a pretty girl named Eileen, and the two fathers often spoke half-seriously of uniting their first-born. Dante Conway warned James that if he played with Eileen he would certainly go to hell,... (Ellmann, p. 28).

Dante was fanatic in her belief that one can go to hell just by interacting with Protestants. By hiding under a table, the child manifests his awareness of culpability, even if he does not yet understand his crime. Similarly, acceptance of the intellectual authority of the Church has been instilled into the child at a very young age. Stephen has learned that Dante is a clever and well- read woman, but at the same time he believes that "Father Arnall knew more than Dante because he was a priest" (p.6).

The incident of the quarrel about religion and politics which leaves young Stephen confused is a real life experience of Joyce which project how his consciousness was greatly affected. The image of home as a haven of security and certainty, which sustains Stephen during the lonely torment of his early schooldays at Clongowes, is shattered by the argument over the role played by the Catholic clergy in the downfall of Parnell, which ruins his first Christmas dinner with the adults. What should have been a happy milestone in Stephen's development leaves him "terror- stricken" and confused about the relationship between politics and religion (p.29). Ellmann writes about this incident in Joyce's biography:

Parnell's death made matters worse by overweighting his tragedy with martyrdom. Joyce has described the Christmas dinner in 1891, when his father and John Kelly raged and wept over Parnell's betrayal and death, and Dante Conway, full of venomous piety, left the table. The argument was so acrimonious that the Vances heard it along the street. (p.34).

Dante (who in real life was Hearn Conway) works as a governess and is a fierce partisan of the clergy. In his early life, Stephen is influenced by her religious views. As a devout catholic, Dante thinks that priests must warn the people, direct their lives and tell them what is right and what is wrong (p.29). She thinks that religion must shape social and political life in accordance with divine principles, yet Mr. Dedalus and Mr. Casey appear as secularist and strongly oppose her view of religion and life. They want religion not to meddle in politics (p.29). To them, politics and religion must be separated from each other. Mr. Casey exclaims that "no God for Ireland! We have had too much God in Ireland. Away with God!" (p.36). This fierce argument impinges on Stephen's consciousness negatively. Joyce represents these fictional characters as opposed to each other, yet what is important is that he illuminates his own ambivalent views about religion and politics through his characters without a direct intrusion. As Stephen matures he gains a clearer understanding of the fate of Parnell, and others like him, who devoted their lives to their cause only to be denounced with the complicity of the Catholic clergy. Stephen, who is himself named after a martyr, begins to identify to some extent with Parnell. The undermining of Stephen's confidence in the priesthood, which begins at the Christmas dinner table, is exacerbated by the cruel and arbitrary punishment he receives at the hands of Father Dolan when he accidentally breaks his glasses. This is a real life experience which pained and traumatized Joyce. Ellmann records this incident in Joyce's biography:

The worst event of the early months was the incident described in A Portrait and confirmed by Joyce to Herbert Gorman, when another boy broke 'Stephen's' glasses and 'Father Dolan' pandied the victim on the mistaken premise 
that he had broken the glasses himself to avoid study. Father Dolan was in real life Father James Daly, the efficient prefect of studies at Clongowes for thirty years, and a martinet. Joyce was to speak of him later to Gorman as 'lowbred (p.28).

However, his faith in clerical authority and injustice is restored by the Rector's apparently sympathetic response to his complaint. He resolves to be quiet and obedient despite his triumph. He will not commit the sin of pride. The call to be a good Roman Catholic is pre-eminent, but Stephen's emergent sexuality and his immersion in the works of subversive writers breed unrest and bitter thoughts, which compound his growing skepticism about the religious life, until he is accused of writing a heretical essay. Physical desire alienates Stephen from the life around him and from the rules of religion which had helped shape his earlier identity.

Stephen, who had once conceived of love in spiritual terms as a "holy encounter" in which he would lose his weakness, timidity and inexperience (p.75), now seeks transcendence through sin. Brief moments with prostitutes are succeeded only by a continued awareness of the squalor of his existence. Conscious that his every sin multiplies his guilt and that he faces eternal damnation, Stephen is unable to repent. However, he retains the shell of his former identity, continuing in his prefecture of the sodality of the Blessed Virgin Mary at college. This deep seated hypocrisy at the same time suggests that the religious impulse remains alive in Stephen, for in Catholic doctrine Mary is the refuge of sinners, and signifies intercession and redemption. Stephen's experiences as mentioned here echo those of Joyce as Ellmann reports:

During his fourteenth year... he precociously began his sexual life... On his way home from the theater, where he had seen a performance of Sweet Briar, Joyce walked along the canal bank and met a prostitute. Reckless, curious, and valuing any expression of his own temperament, he experimented, and the experiment helped to fix his image of the sexual act as shameful, an image suppressed but never quite abandoned later (p.7-8).

As proof that his religious upbringing is not in vain and that he is still spiritually conscious in spite of his sins of lust and pride, Stephen feels morally uncomfortable and guilty, because he considers his act of fornication a big sin in relation to religion. "He had sinned mortally not once but many times and he knew that, while he stood in danger of eternal damnation for the first sin alone, by every succeeding sin he multiplied his guilt and his punishment" (p.96). When he attends a school retreat organized in honor of Saint Francis Xavier, the priest's hell-fire sermons move him to anguished self-disgust and terrified remorse just like Joyce in real life as reported in James Joyce:

[...] he was readier than he knew for the retreat which began on November 30, 1896. In charge of the retreat was Father James A. Cullen, and his sermons, delivered, as was customary, according to the prescription of St. Ignatius Loyola's Spiritual Exercises, elicited a more than customary number of twinges from hell-fire. All Joyce's mounting scruples against his own conduct found a fierce justification. He saw himself as a beast, eating like a beast, lusting like a beast, dying like a beast, and dreamed of a pure love for a virgin heart (p.48).

Ellmann writes about Joyce's confession to a Capuchin priest: "He did not confess in the college chapel; to abase himself before Father Henry was still too much to bear. He went instead, according to a sister, to the Church Street chapel. A Capuchin there listened to the tale from a boy of a man's sins with sympathy rather than indignation" (pp.48-49). Joyce like his protagonist Stephen does not confess in the school chapel because of shame and pride. Chapter three focuses almost exclusively on giving an account of the religious retreat that the boys at Belvedere have to make, and it specifically foregrounds the sermons preached by the retreat master, Father Arnall. Although the retreat receives a rather melodramatic representation, heightened by the selective attentiveness of Stephen's overactive imagination, the liturgy itself was a longestablished practice and, as Joyce would have known, one held in particular esteem by the Jesuits.

However, Stephen like Joyce comes to realize that his future cannot be in subjection to an ordered system as in the Church. In his view, the Irish Catholic Church is provincial, narrow and hostile to what he considers important: freedom and justice. On the contrary the Church promotes freedom and responsibility in spite of Joyce's negative view. Gradually, therefore, his soul becomes unable to harbour religious principles for any time though he forces his lips to utter them with conviction. It gives rise to a view of crisis in Stephen, since he thinks that religious rules both confine individuals and cripple their feelings. Through his representation of Stephen, Joyce shows us his own break up with the Catholic Church, but he also encounters the loss of a world of public values. When Stephen gains psychologically more freedom and becomes bolder in his mind, he turns round on politics and religion to question the status quo and its social code that control him. Joyce makes use of his fictional character, Stephen, both to explore an oppositional way of perceiving the world to that of religion and nationalism and to offer a modernist representation of personality as complex, diffuse and unfixed. Stephen's fluid uncertainty is the opposite of Dante and Cranly's coherent views of life, religion and politics. 
In the novel, the representation of Stephen becomes a means for Joyce to represent a view of self in crisis in the early decades of the twentieth century. He does not represent Stephen as complete and coherent throughout the novel. Stephen is continuously seen either as revolting against the cultural, political, family and religious establishment in the late nineteenth-century Irish society or as fragmented and fluid in his desires of freedom, intellectual beauty and harmony. Instead of the identity and meaning constructed by traditional values, Stephen strives to discover his own vocation as subjective in life: he tries to find out his own meaning of life by means of intellectual analysis, rather than accepting blindly the nets of society.

This is a typical modernist tendency. Joyce suggests that the traditional stability of character dissolves and disappears, giving way to a view of identity as indeterminate, unfinished, insubstantial, vague and inconclusive in accordance with the varying and complex modern experience. In response to Joyce's rebellion against traditional Catholic values, Casey in "The Dedalus Dream" comments that there is nothing wrong with the desire to liberate Ireland spiritually. But what is questionable is Joyce's grandiose confidence, shared with his creation Stephen Dedalus, in the fact that he was the one who could initiate this liberation. Joyce was undoubtedly a genius. He had extraordinary vision (despite becoming increasingly blind over the course of his life). But there is something excessive in his belief that he was destined to be the redeemer of Ireland, the bearer of some special insight to which others were not privy. "We can learn from him that tradition should reflect and do justice to the little stories of individual lives and should not ignore them. But we should not follow Joyce, or other writers, in a tendency to dismiss tradition as rigid, arrogant, self-deceptive or tyrannical" (pp.74-75). Casey sums up the negative consequences of rejecting Catholicism in present day Ireland by writing that:

The Christian religion is no longer an important force in the public sphere. Certainly Irish people continue to believe in God and regard themselves as religious. However, their religion has become a private matter, and for society as a whole there is now a moral vacuum where faith used to be. But it is difficult to find a sense of moral direction in this soulless void-a fact reflected in rising rates of suicide, marriage breakdown and violent crime. The consumption of alcohol and drugs is increasing alarmingly...By forgetting this crucial tradition that shaped their culture, Irish people are losing an essential aspect of themselves (pp.71-72).

Religious and moral values are indispensable to humanity. Conrad observes in a letter to Edward Garnett: "I still have some pretensions to the possession of a conscience though my morality is gone to the dogs. I am like a man who has lost his gods" $(1986,2: 198)$ while Joyce responded to the question on when he left the Catholic Church by saying "it is for the church to say".

\section{Conclusion}

The objective of this paper was to demonstrate that Conrad and Joyce converge in the critique of religious hypocrisy and injustice to propose reform although they rejected their Catholic faith for various reasons. They were still spiritually conscious as religious values have been inculcated in them from childhood. The comparison of the works of Conrad and Joyce to explain the importance of autobiographical elements in their projection of spiritual consciousness in the modernist context shows the modernist writer as both subject and creator in his work thus bridging the dichotomy between art and life. The key element in their modernist consciousness is nihilism. The trauma is a consequence of the rejection of God and moral values. Joyce as a high priest of modernism echoes nihilism in his work as he declares through Stephen "I will no longer serve that in which I no longer believe whether it call itself my home, my fatherland, or my church..." (p.222). He will later realize that without God he feels hollow as we see in Stephen his mouthpiece who is culpable of having refused to kneel down and pray at the feet of his dying mother in Ulysses. His embrace of drunkenness in later life is a manifestation of emptiness. Conrad as well echoes his disappointment through Marlow who expresses his disgust at his fellow whites after discovering how hollow they are in the Congo in these words: "I found myself in the sepulchral city resenting the sight of the people...because I felt so sure they could not possibly know the things I knew" (p.1812). Both Conrad and Joyce may have realized that if God is rejected, man and society inevitably become dehumanized and useless. For future research, focus could be on an analysis of artistic consciousness in the same novels by the same authors to demonstrate the role of the modernist writer in the development of the modern British novel and the vision of Conrad and Joyce.

Funding: This research received no external funding.

Conflicts of Interest: The authors declare no conflict of interest. 


\section{References}

[1] Abrams, M. H. (1999). A Glossary of Literary Terms. New York: Heinle \& Heinle

[2] Baron, Father R. (2020). Your Life Does not Belong to You. <www.zenith.org >.

[3] Bulson, E. (2006). The Cambridge Introduction to James Joyce. Cambridge: Cambridge University Press

[4] Burke, C. (2007). Man and Values: A Personalist Anthropology. London: Scepter Publishers, Inc.

[5] Casey, T. G. (2007). The Dedalus Dream. Reflections on Irish Society with the Help of James Joyce's Fiction. The Way, 47(7), 71-83

[6] Conrad, J. (1993). Heart of Darkness. The Norton Anthology of English Literature. Ed. M. H. Abrams., 6 $6^{\text {th }}$ ed. Vol. 2, New York: Norton, 1759 - 1817.

[7] De Marco, Donald \& Benjamin D. Wiker. (2004). Architects of the Culture of Death. San Francisco: Ignatius Press

[8] Ellmann, R. (1983). James Joyce. Revised Edition. Oxford: Oxford University Press

[9]___et al. (1984). Light Rays: James Joyce and Modernism. Ed. E. Heyward. New York: New Horizon Press.

[10] _ _. ed. (1975). Selected Letters of James Joyce. London: Faber and Faber.

[11] Encyclical Letter Fratelli Tutti of the Holy Father Francis on Fraternity and Social Friendship (2020).

[12] Fargnoli, N. A. \& Michael G. P., eds. (1995). James Joyce A- Z: The Essential Reference to His Life and Writings. Oxford: Oxford University Press

[13] Ford, J. (1985). James Joyce and the Conrad Connection: The Anxiety of Influence. Conradiana, 17(1), 3- 18.

[14] Gallacher, I. S. (2017). A Sense of Place in the Writings of Conrad and Joyce. Journal of Nagoya Gakuin University, Language and Culture. 29 (1), 59- 63

[15] Joyce, J. (1964). A Portrait of the Artist as a Young Man. London: Grafton Books

[16] Joyce, S. (1958). My Brother's Keeper: James Joyce's Early Years. ed. Richard Ellmann, New York: Viking

[17] Lester, J. S. (1987). Conrad and Religion. New York: St. Martin's

[18] Lewis, P. (2000). Modernism, Nationalism and The Novel. Cambridge: Cambridge University Press

[19] _ _ . (2006). Religion. A Companion to Modernist Literature and Culture, ed. Kevin J. H. Dettmar and David Bradshaw. Oxford: Blackwell, 19-28

[20] Neary, J. (1999). Like and Unlike God: Religious Imaginations in Modern and Contemporary Fiction, Oxford: Oxford University Press. 47106.

[21] Segall, J. (1993). Joyce in America: Cultural Politics and the Trials of "Ulysses."Berkeley: University of California Press

[22] Stevenson, R. Modernist Fiction. Revised ed. England: Prentice Hall 1998.

[23] Szczeszak - Brewer, A. (2010). Empire and Pilgrimage in Conrad and Joyce. Florida: University Press of Florida

[24] Raskin, J. (1967). Imperialism: Conrad's Heart of Darkness. Journal of Contemporary History, Vol. 2. Literature and Society, Sage Publications, Ltd. 113-131

[25] Trese, L. J. (1998). The Faith Explained. Sinag- Tala Publishers, INC. Manila 